\title{
КОНЦЕПТУАЛЬНЫЕ ПОДХОДЫ В СТРАТЕГИИ ЭКОНОМИЧЕСКОЙ БЕЗОПАСНОСТИ
}

\section{(c) 2020 Лебедев Анатолий Тимофеевич}

доктор технических наук, профессор, заведующий кафедрой технического сервиса, стандартизации и метрологии Ставропольский государственный аграрный университет, Россия, Ставрополь

\section{(c) 2020 Жевора Юрий Иванович}

кандидат экономических наук, доцент, профессор кафедры технического сервиса, стандартизации и метрологии Ставропольский государственный аграрный университет, Россия, Ставрополь

\section{(c) 2020 Павлюк Роман Владимирович}

кандидат технических наук, доцент,

профессор кафедры технического сервиса, стандартизации и метрологии Ставропольский государственный аграрный университет, Россия, Ставрополь

\section{(c) 2020 Глебова Екатерина Николаевна} магистр

Ставропольский государственный аграрный университет, Россия, Ставрополь

\section{(c) 2020 Польшаков Александр Андреевич} студент

Ставропольский государственный аграрный университет, Россия, Ставрополь

Изложены концептуальные подходы в стратегии экономической безопасности и роли государства. Данные подходы отражают принцип классической политической экономии, означающий минимизацию вмешательства государства в экономику и свидетельствуют о возросшем влиянии школы институционализма на мировоззренческие и управленческие концепции устойчивости развития экономики.

Ключевые слова: Концепция, стратегия, безопасность, экономика.

В современных условиях развития мировой экономики перед Россией стоит главная проблема государства, общества и экономики по обеспечению национальных интересов в сфере экономического развития и в первую очередь трансформационным процессам совершенствования институтов социально-экономического устройства государства и механизмов экономического регулирования на региональном уровне.

В целях реализации государственной национальной политики систему обеспечения экономической безопасности необходимо рассматривать как регулирующий инструмент в обеспечении общенациональных интересов страны.

Приведенный подход к роли государства в экономической безопасности базируется на нескольких принципах. В первую очередь, отражает ограниченность принципа классической политической экономии laissez-faire (минимизации вмешательства государства в экономику) и характеризует возросшее влияние школы институционализма на управленческие концепции в экономике [1].

Согласно институциональной теории, становление государства, как субъекта, в первую очередь определяется неперсонифицированными требованиями и договорными отношениями. Отсюда, субъектам экономики страны необходимо, для снижения трансакционных издержек, создавать систему коллективной безопасности, дающее государству право на принуждение для ее обеспечения и представляющее конституционную основу современного государства в мире [2]. Так же, «государство можно рассматривать как инструмент, служащий для уменьшения трансакционных издержек посредством использования принуждения» - подчеркивает 


\section{В.А. Козбаненко [3].}

Таким образом, государство является основным инструментом обеспечения национальной безопасности в стране. При этом, национальная безопасность является как важнейшей задачей, так и исключительной обязанность государства [4]. Это подтверждает и Е.А.Олейников: «...существуют проблемы, относящиеся к исключительной прерогативе государства. Никто, кроме государства, их просто не может решить. К числу проблем относится и обеспечение экономической безопасности страны. Строго говоря, самая необходимость существования государства обусловлена наличием проблем подобного уровня. Если бы можно было решать без его участия, то государство стало бы ненужным» [5].

Важнейшей функцией государства является обеспечение стабильности в обществе, его развитие и отражение возможных внутренних и внешних угроз национальной безопасности страны. Таким образом, государство должно создать систему предупреждения угроз экономической безопасности.

Экономическая безопасность как система, по мнению некоторых ученых, в нашем стране отсутствует. Так, А.Д.Урсул утверждает: «отсутствие со стороны государства какой-либо систематической работы по обеспечению экономической безопасности дает основание утверждать, что у нас не существует системы экономической безопасности. Попытки ее создания предпринимались, правда, и Советом Безопасности, и Федеральным Собранием, разработана система критериев. Но как работающая система, обеспечивающая экономическую безопасность, она не существует». Одной из причин отсутствия системы обеспечения экономической безопасности страны является определение транзакций как несистемообразующих издержек [6].

Поэтому, без усиления роли государства, централизации организованного насилия и систематизации экономических отношений в обеспечении экономической безопасности, то есть сокращения трансакционных издержек, экономическое развитие страны замедляется. Необходимо превращение органов юстиции в общественную потребность, предоставляемое органами государственной власти в обмен на уплату налогов с юридических и физических лиц.

Таким образом, усиление роли государства будет эффективным, если для охраны жизни и собственности граждан будет создана надежная система экономической безопасности на региональном уровне. Современный этап развития российской государственности имеет ключевое значение при решении региональных проблем безопасности [7].

Обеспечение национальных интересов страны зависит от возможностей государственного регулирования процессов социальноэкономического развития в условиях нестабильности: политических, информационных, техногенных и других факторов, направленных на ликвидацию угроз национальным интересам.

Обеспечение экономической безопасности включает четыре основных цикла: поступление угрозы во внутреннюю среду экономической системы; определение уровня угрозы и ее возможного отрицательного эффекта; выбор механизмов принятия решений по отражению угрозы; трансформация и конвертируемость угрозы в результате ее нахождения в экономической системе, так называемая «петля обратной связи» [8].

Данная модель применяется в исследовании национальных экономик стран, являющейся открытой системой и эффективно отражающей внешние и внутренние угрозы. Главная цель этой модели заключается в обеспечении равновесия и устойчивости системы путем адаптации к условиям внешней и внутренней среды.

В научных работах отечественных ученых, таких как А.Абалкин, В.В.Медведев, В.Н.Овчинников, Е.А.Олейников, А.А.Петров, О. С. Пчелинцев, В.К. Сенчагов, А. М.Швецов рассмотрены различные подходы в обеспечении экономической безопасности регионов.

В исследованиях В.К.Сенчагова отмечается, что для понимания сущности экономической безопасности необходимо пояснение понятий «развитие» и «устойчивость». Развитие - одно из составляющих компонентов экономической безопасности. Если рост экономики замедляется, то сокращается возможность ее развития и сопротивляемость к внутренним и внешним угрозам [8].

Устойчивость и безопасность - важнейшие характеристики экономики, как единой системы. Устойчивость экономики характеризуется прочностью и надежностью элементов, вертикальных, горизонтальных и других связей внутри системы, способностью противостоять внутренним и внешним угрозам. 
Безопасность - состояние объекта в системе, с точки зрения способности к самосохранению и развитию в условиях внутренних и внешних угроз, а также действий в условиях чрезвычайных ситуаций.

Таким образом, экономическая безопасность определяется как состояние экономики и институтов власти, при котором обеспечивается гарантированная защита национальных интересов, социально направленное развитие страны, достаточный оборонный потенциал при неблагоприятных условиях развития внутренних и внешних факторов.

С целью решения проблемы экономической безопасности в России были созданы Комитет по защите экономических интересов России при Президенте РФ, рабочая группа по экономической безопасности при Правительстве РФ. Впервые, в начале 1995 г. на заседании межведомственной комиссии Совета Безопасности Российской Федерации были обсуждены и приняты основные положения государственной стратегии в области обеспечения экономической безопасности страны.

Указом Президента РФ утверждена «Государственная стратегия экономической безопасности Российской Федерации», в которой «экономическая безопасность» определяется как готовность экономики обеспечить достойные условия жизни и развития личности, социальноэкономическую и военно-политическую стабильность общества и государства, противостоять влиянию внутренних и внешних угроз, что является основой национальной безопасности в целом и всех ее составляющих.

В данной стратегии можно выделить несколько угроз: увеличение имущественной дифференциации населения и повышение уровня бедности, деформирование структуры российской экономики, возрастание неравномерности социально-экономического развития регионов и криминализация хозяйственной деятельности.

Таким образом, в современных условиях развития российской экономики, отечественными учеными были выделены следующие основные угрозы экономической безопасности России: усиление структурной деформации российской экономики с тенденцией превращения ее в топливно-сырьевую базу развитых стран, сокращение научно-технического потенциала, снижение уровня продовольственной безопасности, потеря рычагов управляемости экономикой, криминализация экономики, углубление социальной дифференциации населения, рост безработицы и бедности, нарушение механизма воспроизводства населения страны $[9,10]$.

\section{Библиографический список}

1. Афонцев С. Дискуссионные проблемы концепции экономической безопасности // Россия XXI. 2001. № 2 . с. 25-29.

2. Блауберг И. В. Становление и сущность системного подхода / Блауберг, Э. Г. Юдин. М.: Наука, 1973. $270 с$.

3. Государственное управление: основы теории и организации: учеб.п. в 2 т. Т.1 / под ред. В.А. Козбаненко, 2-е изд., с изм. и доп. М.: Статут, 2002. 366 с.

4. Экономическая безопасность России в XXI веке (методология, теория, практика, отечественный и зарубежный опыт) Учебное пособие. М., Казань, 2004.

5. Экономическая и национальная безопасность: Учебник / под ред. Е. А. Олейникова. М: Издательство Экзамен, 2005.

6. Урсул А.Д. Безопасность устойчивого развития. / А. Д. Урсул, А. Л. Романович. М.: Изд-во РАГС, 2001. с.13.

7. Коротков Э.М. Управление экономической безопасностью общества» / Э. М. Коротков, А.А.Беляев // Менеджмент в России и за рубежом, .№ 6, 2001.

8. Экономическая безопасность России (тенденции, методология, организация) / под ред. В. К. Сенчагова. М.: ИЭРАН, 2000. 498 с.

9. Блохин С.В. Направления укрепления экономической безопасности России в современных условиях / С. В. Блохин. М., РАГС, 2007.

10. Жевора Ю.И., Трысячный В.И., Смольнякова М.О. Институционально-правовые факторы обеспечения экономической безопасности // Устойчивое развитие региона в условиях экономической интеграции России в мировое хозяйство: сб.науч.тр. Ставрополь, 2007. С. 145-147. 